\title{
Origin of Mountain Passes across Continental Divide Segments Surrounding the Southwest Montana Big Hole and Beaverhead River Drainage Basins, USA
}

\author{
Eric Clausen \\ Jenkintown, PA, USA \\ Email: eric2clausen@gmail.com
}

How to cite this paper: Clausen, E. (2017) Origin of Mountain Passes across Continental Divide Segments Surrounding the Southwest Montana Big Hole and Beaverhead River Drainage Basins, USA. Open Journal of Geology, 7, 1362-1385. https://doi.org/10.4236/ojg.2017.79091

Received: August 15, 2017

Accepted: September 16, 2017

Published: September 19, 2017

Copyright $\odot 2017$ by author and Scientific Research Publishing Inc. This work is licensed under the Creative Commons Attribution International License (CC BY 4.0).

http://creativecommons.org/licenses/by/4.0/ (c) (i) Open Access

\begin{abstract}
The evolution of southwest Montana's Big Hole and Beaverhead River drainage basins is determined from topographic map evidence related to mountain passes crossing what are today high altitude drainage divides including North America's east-west Continental Divide. Map evidence, such as orientations of valleys leading away from mountain passes (and saddles) and barbed tributaries found along the downstream drainage routes, is used to reconstruct flow directions of streams and rivers that once crossed the present-day high mountain divides. Large south-oriented anastomosing complexes of diverging and converging channels are interpreted to have eroded what are today closely spaced passes and saddles now notched into high mountain ridges. Water in those south-oriented channels is interpreted to have flowed across emerging mountains and subsiding basins. Headward erosion of deeper southeast-oriented valleys, assisted by crustal warping, concentrated south-oriented water in fewer and deeper valleys as the water flowed from southwest Montana into what are today Idaho and the Snake River drainage basin. Headward erosion of the Big Hole River valley between the emerging Anaconda and Pioneer Mountains, also assisted by crustal warping, reversed all Big Hole Basin drainage so as to create the north-, east-, and south-oriented Big Hole River drainage route. A final and even more major reversal of flow in the present-day north-oriented Montana Missouri River valley, with the assistance of additional crustal warping, next ended all remaining flow to Idaho and the Snake River drainage basin and reversed and captured all drainage in the present-day north-oriented Big Hole, Beaverhead, and Red Rock River drainage basins. The observed map evidence indicates that prior to the final flow reversal events, large volumes of south-oriented water flowed across southwest Montana's Big Hole and Beaverhead River drainage basins.
\end{abstract}




\section{Keywords}

Anaconda Range, Drainage Basin Origins, Missouri River Drainage Basin, Monida Pass, Salmon River, Snake River, Topographic Map Interpretation

\section{Introduction}

For more than a century geologists have debated origins of the southwest Montana Big Hole and Beaverhead River drainage systems (see Figure 1 and Figure 2). Unusual Big Hole and Beaverhead River drainage features attracted the author's attention during his multiyear Missouri River Drainage Basin Landform Origins Project in which topographic map evidence was used to determine how the Missouri River drainage basin originated and evolved. Unpublished Missouri River Drainage Basin Landform Origins Project research notes (in the form of approximately 550 essays in blog format) are available at geomorphologyresearch.com. Understanding Big Hole and Beaverhead River drainage basin histories is critical if the larger Missouri River drainage basin origin is to be understood. While previous researchers agree that water once flowed across high mountain ranges now surrounding the Big Hole and Beaverhead River drainage basins, unfortunately those researchers do not agree on which way the water flowed. Some workers claim that the water flowed in a north direction to what is today a north-oriented Missouri River valley segment and then northward across Canada to the Labrador Sea (considerably north and east of Figure 1). Other researchers are convinced that the water flowed in south directions to the Snake River drainage basin and perhaps even to the Colorado River drainage basin. This paper uses topographic map evidence in an effort to end that controversy.

The Big Hole and Beaverhead River drainage basins are located within the red rectangle outlined in Figure 1, which identifies this paper's study region (shown in more detail in Figure 2). The blue arrows and letters in Figure 1 identify longer drainage routes discussed in this paper with " $M$ "” for the Missouri River, "S" for the Snake River, "F" for Clark Fork, and "C" for the Columbia River. The dashed brown line indicates North America's east-west Continental Divide location. The north-, east-, and south-oriented Big Hole River (BH in Figure 2) drains to the north-oriented Beaverhead River (B in Figure 2) to form the northeast- and east-oriented Jefferson River ( $J$ in Figure 2), which then joins the north-oriented Madison (MA) and Gallatin (GA) Rivers to form the north-, east-, and then predominantly south- and southeast-oriented Missouri River (M) with water eventually reaching the Gulf of Mexico. Study region drainage basins represent the westernmost extent of the large Missouri River (M) drainage basin that covers much of the north central United States. North America's east-west Continental Divide bounds the Big Hole (BH) and Beaverhead (B) River drainage basins on the south, west, and north and follows the crests of surrounding high mountain ranges. South and west of the Big Hole $(\mathrm{BH})$ and Beaverhead (B) River 


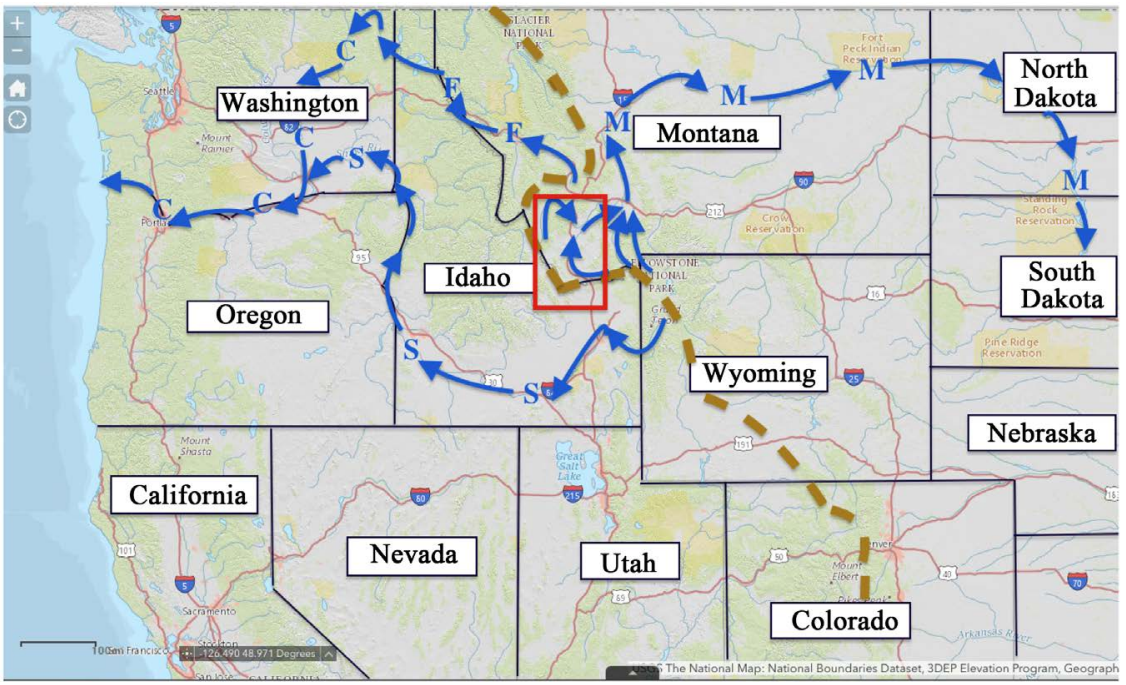

Figure 1. Modified map from the United States Geological Survey (USGS) National Map website. The red rectangle shows the study region. Blue arrows and letters identify major rivers as indicated in the text. The dashed brown line indicates the approximate east-west Continental Divide position. Scale bar in southwest corner represents 100 mile (161 kilometers).

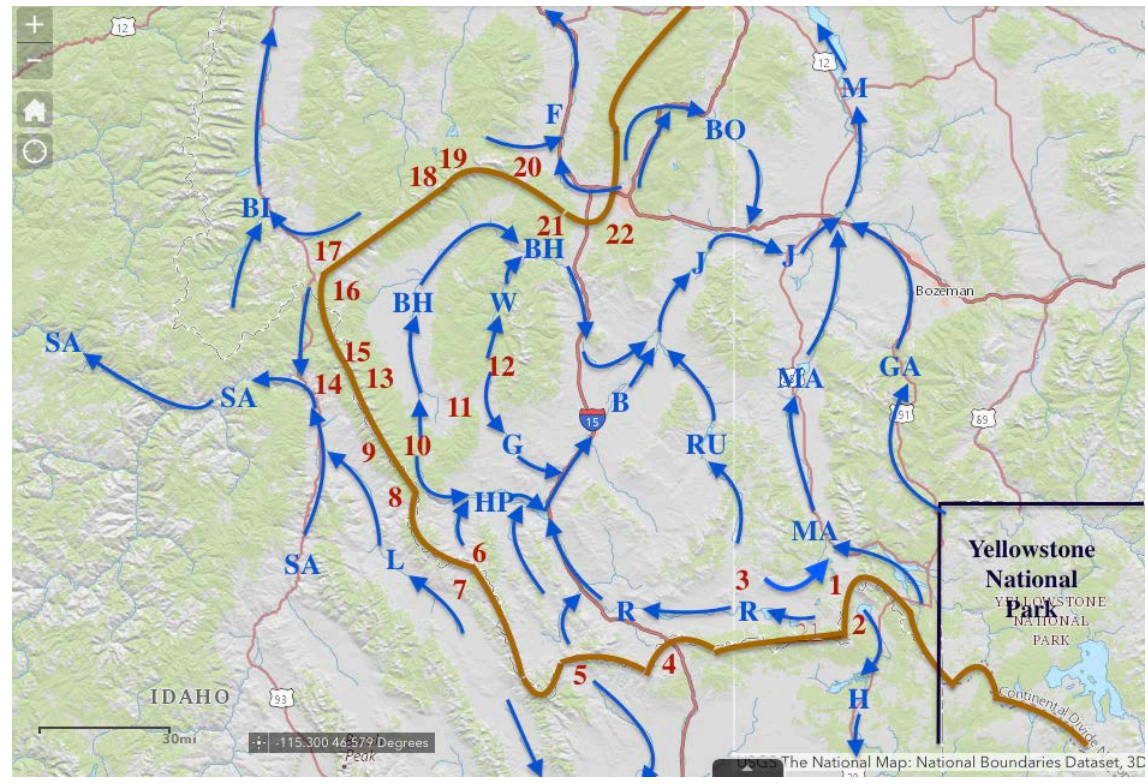

Figure 2. Location of mountain passes shown on a modified map from the USGS National Map website. The brown line follows the east-west Continental Divide. Red numbers identify mountain passes and blue arrows and letters identify drainage routes as indicated in the text. The scale bar in the map southwest corner represents 30 miles (48 kilometers).

drainage basins water drains to the Snake River (S) to eventually reach the Pacific Ocean with the Continental Divide located along Centennial and Beaverhead Mountain Range crests. North and northwest of the Big Hole River (BH) drainage basin water drains to north and northwest oriented Clark Fork where water flows to the Pacific Ocean with the Continental Divide located along the Ana- 
conda Mountain Range crest. Deep mountain passes cross the Centennial, Beaverhead, and Anaconda Mountain Ranges while numerous shallower divide crossings or saddles link streams flowing in opposite directions from the mountain range crests. These deep passes and many, if not all of the shallower saddles are relics of former valleys through which water once flowed. The questions arise, what type of drainage system eroded the deep passes and shallower saddles and which direction did the water flow?

Figure 2 locates by number the 22 pass areas discussed below. Blue arrows and letters indicate drainage routes, which are identified as follows: " $\mathrm{B}$ " Beaverhead River, "BH” Big Hole River, "BI" Bitterroot River, "BO” Boulder River, "F” Clark Fork, "G” Grasshopper Creek, "GA” Gallatin River, "H” Henry's Fork (of the Snake River), "HP” Horse Prairie Creek, "J” Jefferson River, "L” Lemhi River, “M” Missouri River, "MA” Madison River, "R” Red Rock River, "RU” Ruby River, "SA" Salmon River, and "W" Wise River. In addition to passes identified on Figure 2 numerous other passes and saddles near the identified locations are also briefly described to provide a more complete picture of the number and the spacing of the observed divide crossings. In addition to the regional figures this paper provides readers can observe detailed topographic maps of each of the discussed passes using a variety of different map scales at the USGS National Map website [1]. Most mountain passes discussed below have names shown on the detailed topographic maps. However, the detailed maps do not name all of the discussed passes. Unnamed passes have been named in this paper simply to assist with their description.

The north-south highway passing through the study region crosses the east-west Continental Divide at Monida Pass (near study region south edge, number 4 on Figure 2) and also at Deer Lodge Pass (near study region north edge, number 21 on Figure 2). The Monida Pass elevation is 6820 feet (2079 meters) and the Deer Lodge Pass elevation is 5801 feet (1768 meters). Note in Figure 1 and Figure 2 how the Missouri River (M) is formed at Three Forks, Montana where the northeast and east oriented Jefferson River joins the Madison (MA) and Gallatin (GA) Rivers. From Three Forks the Missouri River flows in a north-northwest direction before turning to flow in more of an east direction to North Dakota where it turns again to flow in more of a south direction with water eventually reaching the Gulf of Mexico. Note how the study region is bounded on the north by the north and northwest oriented Clark Fork (F) drainage basin with water eventually reaching the Pacific Ocean and on the south and west by the Snake River (S) drainage basin with water also eventually reaching the Pacific Ocean.

\section{Previous Studies}

For more than a century some workers have suggested water once flowed in a south direction across this paper's study region while others have proposed northward flow. Arguments for south oriented flow began when Umpleby [2] concluded the northwest oriented Lemhi River (L in Figure 2) in Idaho (now flow- 
ing along the Beaverhead Range southwest flank to the north and west oriented Salmon River (SA) previously flowed in a southeast direction to reach eastern Idaho south oriented Snake River (S in Figure 1) valley segments. This interpretation implied all eastern Idaho drainage at that time had been to the Pacific. Not much later Atwood [3] concluded that during Oligocene time all southwest Montana and adjacent Idaho drainage had been to the Pacific with the Continental Divide being located further to the east. Atwood determined late Oligocene, Miocene, and Pliocene volcanic and tectonic activity created interior drainage basins, which became deposition sites while headward erosion of Missouri River tributary valleys captured the southwest Montana drainage. The Big Hole River (BH) according to this scheme originally flowed in a south direction, but was pirated by headward eroding streams and diverted to become the westernmost section of the Missouri River drainage basin.

Arguments for northward flow began when Kirkham [4] proposed approximately 20 miles (37 kilometers) of the headwaters of the present day north oriented rivers had been cut off when the Idaho Snake Riverplain subsided and adjacent mountains emerged to produce the modern day north-oriented drainage routes. However, ten years later Perry [5] agreed with Atwood and Umpleby and proposed major rivers had drained in a south direction across southwest Montana and into Idaho. The north-oriented drainage hypothesis was revived by Anderson [6] who suggested that prior to late Tertiary time much of east central Idaho had drained in a northeast direction to the present day north-oriented Montana Missouri River valley and late Tertiary stream piracy had moved the east-west Continental Divide approximately 100 miles (160 kilometers) to the east. Based on the presence of gravel in Beaverhead Mountain Range passes Scholen, Keenmon, and Kupsch [7] also suggested east central Idaho drainage had once flowed northward into Montana. But Ruppel [8] in a study of Idaho gravel deposits supported south oriented drainage from the Big Hole River (BH) drainage basin into Idaho. Bayrd [9] working near the study region's southeast corner concluded drainage once flowed in a south direction to where the modern day Colorado River and its south oriented Green River tributary are now located (not shown in figures here, but in Colorado which is seen in Figure 1).

Most recently, without addressing geomorphic or other evidence earlier workers (such as those cited above) presented, Sears [10] [11] proposed a major north-oriented river flowed from the Grand Canyon area (south of Figure 1) northward across eastern Idaho and southwest Montana and then followed the north-oriented Montana Missouri River alignment to finally reach northern Canada. Evidence used by Sears included Miocene and Pliocene river gravel found on the Continental Divide near Monida Pass, north to south oriented valleys in Utah and Nevada, and the hypothesized pre-ice age Bell River system that includes Montana Missouri River valley segments and that flowed into and across Canada and finally to the Labrador Sea (based on sediments McMillan [12] describes). Clausen [13], who had recently posted Missouri River drainage 
basin landform origins research project notes in blog format at geomorphologyresearch.com, responded to the Sears paper and argued south-oriented flow in the north-south oriented Utah and Nevada valleys was more likely than north-oriented flow. He suggested melting of a thick North American ice sheet could generate the immense volumes of water necessary to erode the valleys in question and further briefly described how melt water from a thick ice sheet that had created and occupied a deep "hole" would eventually reverse its flow direction as the ice sheet melted so as to create all of the north-oriented valleys in the hypothesized pre-ice age Bell River system. Sears [14] in his reply to the Clausen's comment noted the Miocene and Pliocene ages of sediments in Montana north-oriented valleys was not consistent with Pleistocene ages of North American ice sheets and concluded the age inconsistency "falsified" Clausen's hypothesis.

While there has been considerable disagreement concerning which way water flowed across this paper's study region interestingly there has also been remarkable agreement that large rivers did once flow across that Continental Divide and that crustal warping and volcanic activity played important roles as those rivers were dismembered. There also has been agreement that flow in at least some segments of the dismembered river valleys has been reversed so as to create present day drainage systems, although there is considerable disagreement as to which modern day valley segments contain the reversed flow. There also seems to be agreement among researchers who advocate different flow directions that large rivers flowing one way or the other used at least some of the north to south oriented valleys located to the south of this paper's study region. This paper is intended to continue the discussion by summarizing topographic map evidence, much of which has been described in great detail in Missouri River drainage basin landform origins research project notes (available in blog format at geomorphologyresearch.com), to document geomorphic evidence suggesting south-oriented water eroded the present day high mountain passes and saddles and that major flow reversals created the present day north-oriented Big Hole (BH) and Beaverhead River (B) drainage basins. While this paper does not address the water source(s) or when during the geologic time water last flowed across the Continental Divide the paper does present evidence that immense volumes of south-oriented water once crossed southwest Montana and the Continental Divide segments of interest.

\section{Research Method}

Mountain passes and drainage routes in southwest Montana were among the many intriguing Missouri River erosional landforms studied during the author's much larger and unpublished Missouri River drainage basin landform origins research project. The Missouri River drains the north central United States including most northern Great Plains and Rocky Mountain regions located to the east of the North American east-west continental divide and the Missouri River 
also drains small areas in the Canadian provinces of Alberta and Saskatchewan. The multi-year Missouri River drainage basin landforms origins research project consisted of systematically studying detailed topographic maps of the entire Missouri River drainage basin and most adjacent drainage basins to determine how major drainage divides within and surrounding the Missouri River drainage basin originated. Drainage divide origins were determined by using divide crossings (through valleys, mountain passes, wind gaps, saddles, etc.) as evidence of previous drainage routes and then using barbed tributaries, elbows of capture, asymmetric drainage divides, and similar evidence to determine how thousands of capture events altered earlier drainage routes so as to produce Missouri River drainage basin drainage routes that exist today.

The southwest Montana study described here used detailed topographic maps from the United States Geological Survey (USGS) Historical Map Collection website [15] and the USGS National Map website [1]. The study used 1:250,000 scale maps when observing larger regions while more detailed 1:24,000 scale maps were used when observing areas of special interest. The study began by identifying deeper mountain passes along the east-west Continental Divide (Missouri River-Snake River and the Missouri River-Clark Fork drainage divides) and also along the Big Hole River-Beaverhead River drainage divide. Each major drainage divide was also inspected to observe less obvious divide crossings such as saddles at the heads of opposing streams (flowing from the drainage divide in opposite directions). Each such divide crossing, whether a deep named mountain pass or a shallow saddle linking two opposing stream valleys, was considered to be evidence of a previous drainage route that once crossed what is now a major drainage divide. Orientations of valleys that now drain in opposite directions from these divide crossings were used to identify previous drainage route orientations, although in many cases those orientations could not be used to identify the previous drainage route flow direction. Previous flow directions were determined by looking for barbed tributaries and elbows of capture along downstream valleys to identify valleys in which the flow direction had once been the reverse of what it is today. The number and spacing of divide crossings was also used to determine the nature and characteristics of the previous drainage systems.

\section{Results}

\subsection{Red Rock River Drainage Basin}

Mountain passes numbered 1 - 5 on Figure 2 and Figure 3 cross mountains and ridges surrounding the west and northwest oriented Red Rock River (R) drainage basin. The Red Rock River (R) joins east and southeast oriented Horse Prairie Creek (HP) to form the north-oriented Beaverhead River (B), which joins the north-, east-, and south-oriented Big Hole River (BH) and north-oriented Ruby River (RU) to form the northeast- and east-oriented Jefferson River. The Jefferson River (J) then joins the north-oriented Madison (MA) and Gallatin 


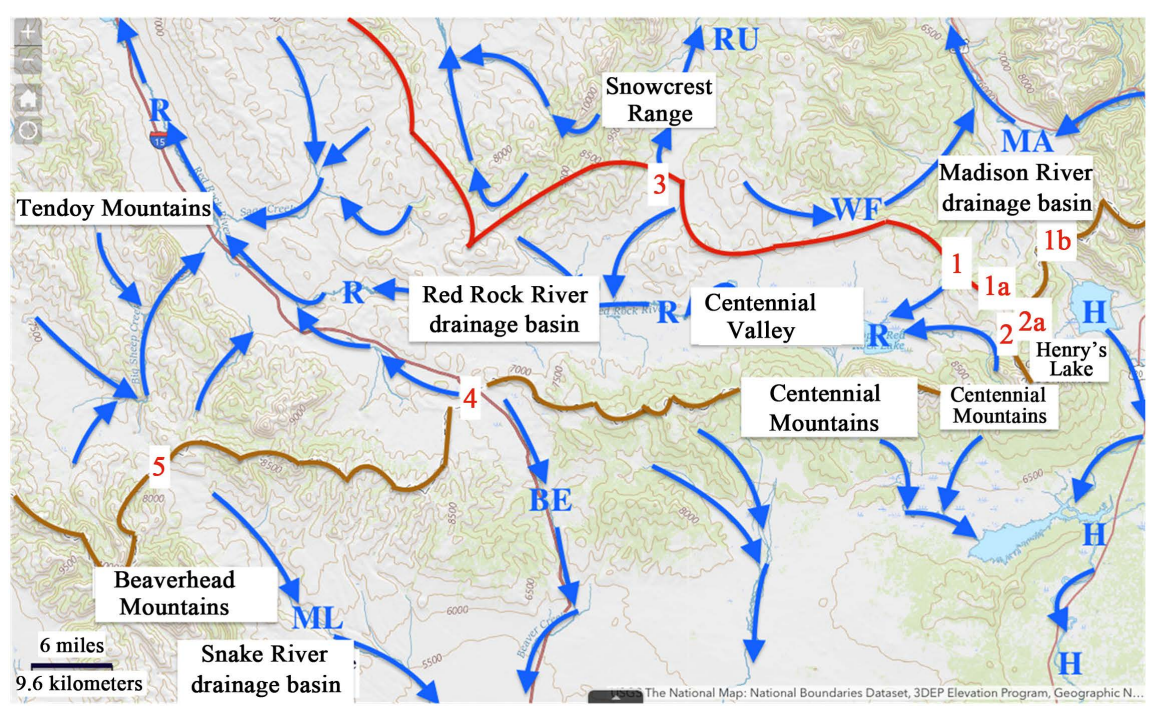

Figure 3. Modified section of USGS National Map website map showing locations of passes 1 - 5. Red numbers show pass locations and blue letters identify drainage routes as indicated in the text. A brown line follows the Continental Divide and a red line follows Red Rock River drainage basin divide with north oriented Missouri River tributaries.

(GA) Rivers to form the north-oriented Missouri River (M), which eventually turns in an east and then south direction. The Centennial Mountains form the Continental Divide ridge south of the west-oriented Red Rock River (R), which flows in a structural depression known as the Centennial Valley (see Figure 3). A low mountain ridge forms divides at the Centennial Valley east end between the west-oriented Red Rock River drainage basin and south-oriented Henry's Fork of the Snake River (H) valley and north-oriented Madison River (MA) valley. Low ridges also form the divide between the Red Rock River (R) and the southeast-, east-, and northeast-oriented West Fork Madison River (WF in Figure 3) and the north oriented Ruby River (RU).

1) Hidden Lake Pass (number 1 on Figure 2 and Figure 3) links the west oriented Red Rock River (R) drainage basin with the northwest and north oriented Madison River (MA) drainage basin. The name Hidden Lake Pass is used here for a narrow northeast trending structural valley described by Gary [16], Hill [17], and others that today contains a chain of narrow lakes. The lowest drainage divide elevation on this valley's hummocky floor is 6840 feet (2085 meters), although today hummocky ridges separate multiple water filled depressions. Gary, Hill, and other previous workers described this valley as the former outlet of one or more Pleistocene lakes that partially filled the Centennial Valley. They suggest lake water flowed through the valley in a northeast direction to reach the north oriented Madison River (MA). Landslides, perhaps triggered by earthquakes, blocked the valley to produce the present day hummocky valley floor and to also force the Centennial Valley Pleistocene lake water to flow in a west direction and to erode what is today the west- and northwest-oriented Red Rock River (R) valley. 
Figure 3 illustrates the Hidden Lake Pass (number 1 on Figure 2 and Figure 3) location in relation to the west-oriented Red Rock River (R) headwaters, the south-oriented Henry's Fork (of the Snake River) (H) headwaters, the east-oriented West Fork Madison River (WF), and Lone Tree (1a) and Raynolds (1b) Passes. While the previously described Pleistocene lake(s) probably drained in a north direction through Hidden Lake Pass (1) adjacent passes also seen in Figure 3 suggest most pass valley erosion was done by south-oriented water. Evidence for earlier flow across the present-day Red Rock-Madison River drainage divide is found at Lone Tree Pass (number 1a on Figure 3 with an elevation of 7521 feet or 2292 meters), which links a north-oriented Madison River tributary with a southwest-oriented Red Rock River tributary. Lone Tree Pass (1a) does not cross the Continental Divide, but is located adjacent to it. Determining the direction water once moved across Lone Tree Pass requires knowing the flow direction of water that once moved across nearby passes that do now cross the Continental Divide. Three of these passes are south of Lone Tree Pass and link the Red Rock River (R) drainage basin with the Henry's Fork of the Snake River (H) drainage basin. Still another pass, Raynolds Pass (number $1 \mathrm{~b}$ with an elevation of 6836 feet or 2084 meters) is located east of Hidden Lake Pass (1) and northeast of Lone Tree Pass (1a) and links the north-oriented Madison River (MA) valley with the south-oriented Henry's Fork $(\mathrm{H})$ valley. The question that needs to be answered is did water flow to the north in the Henry's Fork $(\mathrm{H})$ valley to reach the north-oriented Madison River (MA) valley or did water flow to the south in the Madison River valley to reach the south-oriented Henry's Fork $(\mathrm{H})$ valley?

2) Red Rock Pass (number 2) with an elevation of 7135 feet or 2180 meters, Squaw Pass (2a) with an elevation of 7276 feet or 2218 meters and an unnamed pass (also at 2a) with an elevation of 7410 feet or 2259 meters are passes located just south of Lone Tree Pass (1a) and they do cross the Continental Divide. Red Rock (2) and Squaw Pass (2a) are oriented in west-east directions while the unnamed pass (next to Squaw Pass at 2a) to the north is oriented in a northwest-southeast direction. The Henry's Fork $(\mathrm{H})$ valley is oriented in more of a north-south direction and as already mentioned is linked at Raynolds Pass (1b) with the north-oriented Madison River (MA) valley. These valley orientations make it unlikely that water flowed in a north direction in the Henry's Fork $(\mathrm{H})$ valley and then turned in a west direction to enter the Centennial Valley and the Red Rock River (R) drainage basin. The much more probable flow direction for water that eroded these three passes was in an east direction to a south-oriented Henry's Fork $(\mathrm{H})$ valley. If so the present day west-oriented Red Rock River (R) drainage route originated as an east-oriented drainage route and its flow direction has been reversed.

3) Centennial Divide (number 3) with an elevation of 7360 feet or 2500 meters is the name used for the divide between the north-oriented Ruby River (RU in Figure 2 and Figure 3) valley and drainage to southwest and south oriented Long Creek, which flows to the west-oriented Red Rock River (R). East of Cen- 
tennial Divide are headwaters of the southeast-, east-, and northeast-oriented West Fork Madison River (WF on Figure 3). Landon Ridge separates the east-oriented West Fork Madison River (WF) from the west-oriented Red Rock River (R) although low areas on Landon Ridge suggest water once flowed across it. The southeast-, east-, and northeast-oriented West Fork Madison River (WF) drainage route suggests the flow direction across Landon Ridge was much more likely to have been in a south direction than the reverse. If water once moved in a south direction across Landon Ridge then water probably also moved in a south direction in the present day north-oriented Ruby River (RU) valley and then across Centennial Divide to reach what is now the Red Rock River (R) drainage basin.

4) Monida Pass (number 4 on Figure 2 and Figure 3) has an elevation of 6820 feet (2079 meters). Sears [10] described Monida Pass as threading its way through the gap between the east-oriented Centennial Mountains and the northwest-oriented Tendoy Mountains "in non-resistant Miocene/Pliocene river gravel and weak [and] underlying Aspen Shale of Cretaceous age". He continued by citing work done by Beranek et al. [18] to suggest a north-oriented upper Snake River (S in Figure 1) once flowed west of Monida Pass to the north-oriented Beaverhead River ( $B$ in Figure 2) valley and that the river was progressively deflected by mountain uplift to flow in the valley that now crosses Monida Pass before tectonic and volcanic activity forced the river to flow along its present day southwest and west route. Today the upper Snake River (S) in northwest Wyoming flows in a south direction and then turns abruptly to enter Idaho and flow in a northwest direction before it turns in a southwest and west direction (see Figure 1). The eastern Idaho northwest oriented Snake River (S) valley segment does appear to be aligned with Monida Pass and the northwest-oriented Red Rock River (R) valley.

However, this northwest-oriented Snake River (S) hypothesis has several major problems. First, multiple south-oriented tributaries join the northwest-oriented Red Rock River (R) valley and the downstream north-oriented Beaverhead River (B) valley and suggest flow in those valleys has been reversed. Second, a ridge separates the northwest-oriented Red Rock River (R) valley from the northwest-oriented valley draining from the Monida Pass north side. Gaps eroded across that ridge suggest water once flowed across it. Elevations of those gaps are almost identical to the Monida Pass elevation and the gap orientations suggest erosion was by southeast-oriented water that turned to flow in an east direction. Third, the Monida Pass elevation is almost identical with the Hidden Lake Pass (1) elevation (after allowing for landslide debris now filling the valley) and the Raynolds Pass elevation between the north-oriented Madison River (MA) and south-oriented Henry's Fork $(\mathrm{H})$ valleys. These elevations suggest water flowed in a southeast direction to Monida Pass and also in an east direction to Hidden Lake Pass (1) just before the Red Rock River (R) flow reversal took place. 
5) Bannack Pass (number 5 on Figure 2 and Figure 3) with an elevation of 7674 feet or 2339 meters is located on a relatively narrow ridge linking the northwest-oriented Tendoy Mountains with the northwest-oriented Beaverhead Mountains (located to the west). South of Bannack Pass water now flows in a southeast direction through a structural valley to reach southeast-oriented Medicine Lodge Creek (ML on Figure 3) that then flows toward the Snake River (S in Figure 1). North of Bannack Pass is a northwest-oriented structural valley between the two mountain ranges although the valley floor closest to the pass is drained in a north direction through a deep valley that has been eroded across the Tendoy Range to reach the northwest-oriented Red Rock River (R). Further north the structural valley floor is drained in a northwest and north direction (see Figure 4) to east- and southeast-oriented Horse Prairie Creek (HP), which joins the Red Rock River (R) as a barbed tributary to form the north-oriented Beaverhead River (B). Sears [10] suggested that before being deflected to the Monida Pass route the northwest-oriented Snake River (S) flowed between the Beaverhead and Tendoy Mountains. Such an interpretation is extremely unlikely because the initial north-oriented flow route would have required a southeast-oriented jog around the Tendoy Mountains north end (see Figure 4) and also because any deflection process would have been extremely complex.

\subsection{Beaverhead Mountain Passes across the Horse Prairie Creek-Lemhi River Drainage Divide}

1) Deadman Pass and Bannock Pass (numbers 6 and 7 on Figure 2 and Figure 4) with elevations of 7748 feet (2362 meters) and 7679 feet (2341 meters) respectively have similar elevations, which are remarkably similar to the previously

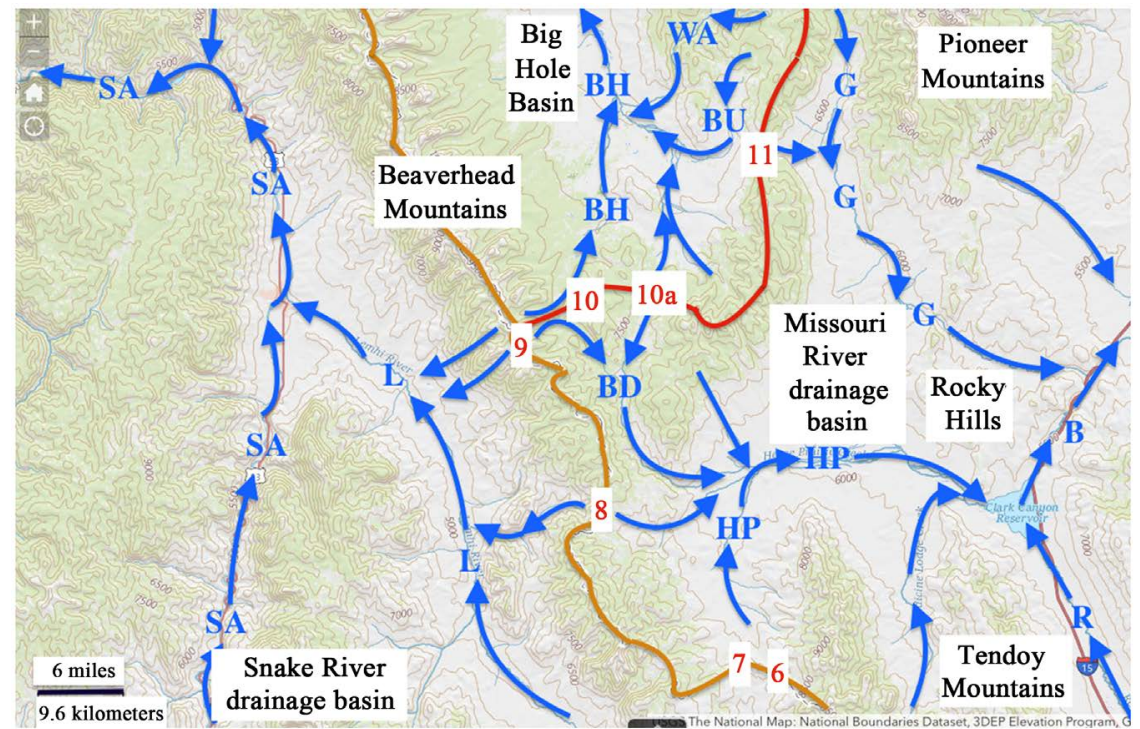

Figure 4. Modified section of USGS National Map website map showing locations of passes 6 - 11. Red numbers show pass locations and blue arrows and letters identify drainage routes as indicated in the text. A brown line follows the Continental Divide and a red line follows the Big Hole Divide. 
described Bannack Pass elevation of 7674 feet (2339 meters). Deadman Pass is the easternmost of the two passes both of which represent low points on an east-west oriented ridge linking wider segments of the northwest trending Beaverhead Mountains. Drainage south of that ridge is to south oriented Canyon Creek, which as a barbed tributary flows through Railroad Canyon to reach the northwest-oriented Lemhi River (L). North of the Deadman-Bannock Pass ridge drainage is to north-, east-, and southeast-oriented Horse Prairie Creek (HP), which joins the northwest-oriented Red Rock River $(\mathrm{R})$ as a barbed tributary to form the north-oriented Beaverhead River (B).

The barbed tributaries provide evidence that flow across the Deadman-Bannock Pass ridge (and also in the Red Rock (R)-Beaverhead River (B) and Lemhi River (L) valleys) originally was in a south direction. The similarity of the Bannack, Deadman, and Bannock Pass elevations suggests diverging and converging south-oriented river channels may have eroded the three different passes. If so the south-oriented diverging river channels must also have included flow channels that eroded Monida Pass and passes at the Centennial Valley east end such as Red Rock Pass (2). Huge volumes of water would have been required to initiate and maintain multiple south- and southeast-oriented river channels as the Beaverhead, Tendoy, and Centennial Mountains were being uplifted.

2) Lemhi Pass (number 8 on Figure 2 and Figure 4) with an elevation of 7373 feet or 2247 meters represents a saddle approximately 1000 feet (305 meters) lower than the mountain crest to the north. Lemhi Pass is located on a narrow ridge between the southeast-oriented Trail Creek headwaters valley and the deep northwest-oriented Agency Creek headwaters valley. Further downstream Trail Creek turns in a northeast direction to join east- and southeast-oriented Horse Prairie Creek (HP) with water eventually reaching the Missouri River (M). Downstream from its northwest-oriented headwaters Agency Creek turns in a southwest and northwest direction before flowing in a southwest and west direction to join the north- and northwest-oriented Lemhi River (L) with water eventually reaching the Salmon River (SA). The northwest and southeast orientation of valley segments closest to Lemhi Pass suggests either northwest- or southeast-oriented flowing water once moved through the pass. Based on evidence for previously described passes southeast-oriented water provides a much simpler explanation for the eight passes discussed so far than northwest-oriented flow.

3) Goldstone Pass (number 9 on Figure 2 and Figure 4) with an elevation of 9010 feet or 2771 meters is much higher than the previously discussed passes, but like Lemhi Pass is a low point on a narrow glacially carved ridge (arête) linking even higher mountain peaks on either side. Goldstone Pass is typical of many similar saddles notched into the high Beaverhead Mountain crest. A deep northeast-oriented Bloody Dick Creek (BD in Figure 4) headwaters valley drains the Goldstone Pass east side while a deep west-oriented Pratt Creek headwaters valley drains the west side. Downstream from its headwaters valley Bloody Dick Creek (BD) turns abruptly in a southeast direction and eventually joins east- and 
southeast-oriented Horse Prairie Creek (HP). After flowing in a west direction Pratt Creek turns to flow in a southwest direction to eventually join the northwest-oriented Lemhi River (L) as a barbed tributary. Orientations of valleys closest to Goldstone Pass suggest southwest-oriented water eroded the pass (prior to Beaverhead Mountain glaciation) with the southwest-oriented flow being subsequently captured and reversed by headward erosion of the deeper southeast-oriented Bloody Dick Creek (BD) valley. Since that time mountain uplift and water and ice erosion have further altered the present day valleys.

There are numerous closely spaced high altitude saddles along the Beaverhead Mountain Range crest north of the Goldstone Pass saddle. Deep northeast-oriented and deep southwest-oriented valleys are found closest to most, but not all of these saddles suggesting the saddles are relics of valleys that a closely spaced network of southwest-oriented streams or rivers carved into an emerging Beaverhead Mountain Range. Headward erosion of the deep southeast-oriented Bloody Dick Creek (BD) valley captured the southwest-oriented flow in the region south of the Goldstone Pass area and as described below may have also done so in the region north of Goldstone Pass, although today the north-oriented Big Hole River $(\mathrm{BH})$ drains that region. The Beaverhead Mountain Range crest north of the Goldstone Pass area was glaciated after the multiple closely spaced southwest oriented streams or rivers had eroded southwest- and northeast-oriented valleys into the emerging mountain range and the southwest-oriented flow had been blocked by mountain range uplift and captured by Bloody Dick Creek (BD) valley headward erosion.

\subsection{Passes across the Big Hole-Beaverhead River Drainage Divide}

1) Big Hole River-Bloody Dick Creek Pass (number 10 on Figure 2 and Figure 4) with an elevation of 7575 feet (2309 meters) is the name used here for a pass across the Big Hole Divide. The Big Hole Divide refers to the drainage divide between north-oriented Big Hole Basin drainage and the north-oriented Beaverhead River to the east. Understanding the Big Hole Divide origin is critical if the Big Hole River (BH) and Beaverhead River (B) drainage history is to be deciphered. The Big Hole River (BH) begins in a cirque north of Goldstone Pass as Darkhorse Creek, which after flowing in a northeast direction turns in a north direction to become the north-oriented Big Hole River $(\mathrm{BH})$. A low divide on the floor of a 1500-foot (457-meter) deep pass separates the north-oriented Big Hole River (BH) valley from the southeast-oriented Bloody Dick Creek (BD) valley. The pass floor at its lowest point is only about 100 feet (30 meters) higher than the Big Hole River (BH) valley floor elevation just to the north. This 1500 -foot (457-meter) deep pass was most likely eroded when a deep south- and southeast-oriented valley eroded headward across multiple southwest-oriented flow channels along what are now the southeast-oriented Bloody Dick Creek (BD) and north-oriented Big Hole River (BH) alignments. A reversal of flow in the Big Hole Basin, probably caused by tectonic activity, subsequently created the north-oriented 
Big Hole River $(\mathrm{BH})$ route found to the north of what is now Big Hole River-Bloody Dick Creek Pass. The deep pass at location 10a on Figure 4 was also probably eroded by south-oriented water moving from the Big Hole Basin to the Bloody Dick (BD) valley. Trying to explain how north-oriented flow could have eroded these two deep passes (10 and 10a) is much more complicated than trying to explain how south-oriented flow eroded the two passes.

2) Big Hole Divide Pass (number 11 on Figure 2 and Figure 4) with an elevation of 7440 feet or 2268 meters is located on a ridge linking a high mountainous area to the south and the Pioneer Mountains to the north. Drainage to the east is to south- and southeast-oriented Grasshopper Creek (G), which joins the north-oriented Beaverhead River (B) as a barbed tributary. Drainage to the west is to south- and northeast-oriented Bull Creek (BU in Figure 4), which flows to northeast-oriented Governor Creek and then to the north-oriented Big Hole River (BH). Big Hole Divide Pass was almost certainly eroded by east-oriented water moving to the south- and southeast-oriented Grasshopper Creek (G) valley. While some east-oriented water may have come from the Big Hole Basin and then turned in a northeast direction to reach Big Hole Divide Pass probably most of the water that eroded Big Hole Divide Pass moved in a south direction from the Pioneer Mountains along what is now the south-oriented Bull Creek (BU) alignment. An unnamed pass with an elevation of 8033 feet (2448 meters) links Bull Creek (BU) headwaters in the Pioneer Mountains to north- and west-oriented Old Tim Creek, which flows to south- and west-oriented Warm Springs Creek (WA in Figure 4), which flows to the north-oriented Big Hole River (BH). A lower elevation pass with an elevation of about 7640 feet (2329 meters) links the Old Tim Creek valley with a northeast-oriented tributary to the north-oriented Wise River (W) valley. These and other Pioneer Mountain passes suggest that at least some of the water flowing south on the Bull Creek (BU) alignment to erode Big Hole Divide Pass must have flowed across the top of what are now the Pioneer Mountains.

3) Wise River-Grasshopper Creek Pass (number 12 on Figure 2 and Figure 5) has an elevation of about 7700 feet (2347 meters) and is used by the north to south oriented Pioneer Mountain National Scenic Highway. Wise River-Grasshopper Creek Pass is the term used here for a low divide between Harrison Park, which drains in a south direction to south- and southeast-oriented Grasshopper Creek (G) and Moose and Mono Parks, which drain in a north direction to the north-oriented Wise River (W). The parks represent relatively level swamp areas with a 40 - 80 foot (12 - 25 meters) high ridge forming the drainage divide. East of the park areas are high glaciated mountain peaks while to the northwest Seymore Mountain rises more than 1000 feet (305 meters) above the Wise River-Grasshopper Creek Pass floor. Today the north-oriented Wise River (W) joins a southeast-oriented Big Hole River $(\mathrm{BH})$ segment north of the Pioneer Mountains at an elevation of approximately 5600 feet (1707 meters) while south- and southeast-oriented Grasshopper Creek (G) joins the north-oriented 


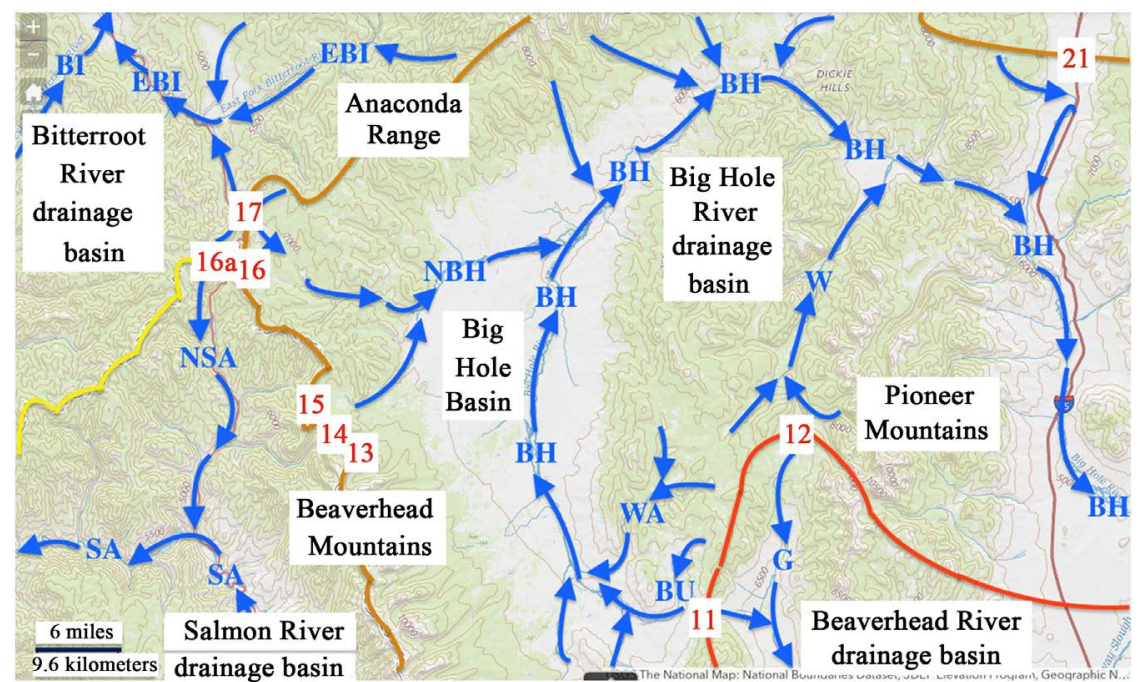

Figure 5. Modified section of USGS National Map website map showing locations of passes $11-17$ and of pass 21. Red numbers show pass locations and blue arrows and letters identify drainage routes as indicated in the text. A brown line follows the Continental Divide, a red line follows Big Hole River-Beaverhead River drainage divide, and a yellow line follows the Bitterroot River-Salmon River drainage divide.

Beaverhead River (B) as a barbed tributary at an elevation of approximately 5300 feet (1615 meters). Water that eroded the Wise River-Grasshopper Creek Pass valley almost certainly flowed in a south direction across what is now a 2000 -foot (610-meter) deep Big Hole River (BH) valley to reach the south and southeast oriented Grasshopper Creek $(\mathrm{G})$ valley.

\subsection{Passes across the Big Hole-Salmon River Drainage Divide}

1) Moosehorn Creek Pass (number 13 on Figure 2 and Figure 5) is not named on the topographic maps, but is named here after a stream draining from it. The Pass with an elevation slightly greater than 7400 feet (2256 meters) is a 700-foot (213-meter) deep notch between east-oriented headwaters of Big Moosehorn Creek and the deeper west- and southwest-oriented North Fork Sheep Creek valley. Big Moosehorn Creek flows in an east and north direction to join northeast-oriented Ruby Creek, which in turn flows to the northeast-oriented North Fork Big Hole River (NBH on Figure 5). North Fork Sheep Creek after flowing in a southwest direction joins northwest-oriented South Fork Sheep Creek to form west-, northwest-, and west-oriented Sheep Creek, which then joins the south-oriented North Fork Salmon River (unlabeled south oriented Salmon River tributary on Figure 2 and NSA on Figure 5). The North Fork Salmon River (NSA) flows in a south direction to join the north oriented Salmon River (SA) as a barbed tributary with the combined flow then moving in a west direction to eventually join the north-oriented Snake River (S on Figure 1).

2) Bradley Gulch Pass (number 14 on Figure 2 and Figure 5) is named here after a valley leading away from it and has an elevation of 7140 feet $(2176$ meters). The Pass is an 800 -foot (244-meter) deep north-to-south oriented notch 
linking north- and northeast-oriented Pioneer Creek with south-oriented Bradley Gulch. Pioneer Creek flows to northeast-oriented Ruby Creek and the North Fork Big Hole River (NBH in Figure 5) while Bradley Gulch drains to southwest-oriented North Fork Sheep Creek and as described above eventually to the south-oriented North Fork Salmon River (NSA in Figure 5). Drainage divides at both Moosehorn Pass and Bradley Gulch Pass are asymmetric with steep slopes leading down to North Fork Sheep Creek, which flows in a 1000-foot (305-meter) deep valley below. Gradients to the Big Moosehorn Creek and Pioneer Creek headwaters are much lower and those two creeks then flow along much gentler gradients into the Big Hole Basin. The asymmetric divides and pass orientations strongly suggest both of the passes were eroded by southwest-oriented water moving from the Big Hole Basin to the south-oriented North Fork Salmon River valley.

3) Big Hole Pass (number 15 on Figure 2 and Figure 5) with an elevation of 7055 feet (2150 meters) links an east-oriented Pioneer Creek segment and the northeast-oriented Ruby Creek-North Fork Big Hole River (NBH) with the much deeper valley of west- and southwest-oriented Dahlonega Creek, which flows to the south-oriented North Fork Salmon River (NSA on Figure 5). The drainage divide is asymmetric with steep slopes leading approximately 2000 feet (610 meters) from the Pass into the deep Dahlonega Creek valley. Big Hole Pass is the lowest point on a 700 -foot (213 meters) deep saddle notched into a low elevation north to south oriented Continental Divide segment. The saddle orientation, its width, and the asymmetric divide suggest large volumes of water once moved in a west direction from the Big Hole Basin to the south-oriented North Fork Salmon River valley. Further, the alignment of the North Fork Salmon River valley with the north-oriented Salmon River (SA in Figure 2 and Figure 5) valley to the south suggests flow in the present day north-oriented Salmon River (SA) valley has been reversed.

4) Chief Joseph Pass (number 16 on Figure 2 and Figure 5) with an elevation of 7251 feet (2210 meters) is located just south of where a north-northwest oriented Continental Divide segment turns to being oriented in a north-northeast direction. The Continental Divide both to the north and south of Chief Joseph Pass is significantly lower in elevation than it is in the Beaverhead Mountains to the south and in the Anaconda Mountains to the northeast. Chief Joseph Pass is just one of numerous saddles notched into this lower elevation Continental Divide segment. Chief Joseph Pass is located on a ridge between the south-southwest oriented Moose Creek valley draining to the deep south-oriented North Fork Salmon River and southeast-oriented Chief Joseph Creek (which flows into the Big Hole Basin and then to the northeast-oriented North Fork Big Hole River).

Just west of the Continental Divide and 1 mile (1.6 kilometers) northwest of Chief Joseph Pass is Lost Trail Pass (16a on Figure 5) with an elevation of 7014 feet (2138 meters) which links the south-oriented Moose Creek and North Fork Salmon River valley with north-oriented valleys leading to the north-oriented 
Bitterroot River (BI on Figure 2 and Figure 5) and northwest-oriented Clark Fork (F on Figure 1). Lost Trail Pass was eroded by south-oriented water flowing from what is today the north oriented Bitterroot River (BI) drainage basin to the south-oriented North Fork Salmon River (NSA) valley. Such south-oriented water had also eroded Chief Joseph Pass before southeast-oriented Chief Joseph Creek valley headward erosion captured the flow and diverted the water into the Big Hole Basin. The nearby north-northeast oriented Continental Divide segment was created when south-oriented flow across the Bitterroot River (BI) drainage basin was reversed so as to create the north-oriented drainage basin that exists today.

\subsection{Passes across the Clark Fork-Big Hole River Drainage Divide}

1) Gibbons Pass (number 17 on Figure 2 and Figure 5) with an elevation of 6941 feet (2116 meters) is located between Trail Creek (where it turns from flowing in a southwest direction to flow in a south and southeast direction) and a steep west-southwest facing escarpment leading into a northwest-oriented East Fork Camp Creek tributary valley, which drains eventually to the north-oriented Bitterroot River (BI). Downstream from Gibbons Pass Trail Creek flows for approximately 1 mile (1.6 kilometers) almost on the Continental Divide, which is located on the steep west-facing escarpment rim. At the escarpment base East Fork Camp Creek turns from flowing in a northeast direction to flow in a northwest direction. The southwest-oriented Trail Creek headwaters valley, Gibbons Pass, the northeast-oriented East Fork Camp Creek headwaters valley, Lost Trail Pass, and the Moose Creek valley are all on the same alignment suggesting headward erosion of a southwest-oriented valley from the south-oriented North Fork Salmon River valley captured southeast-oriented water moving from the present day north-oriented Bitterroot River (BI) drainage basin into the Big Hole Basin. Following that capture crustal warping reversed drainage in the western Bitterroot River (BI) drainage basin to create the north-oriented East Fork Camp Creek drainage route which then captured much of the southwest-oriented flow while the southeast-oriented downstream Trail Creek valley also captured some southwest-oriented flow.

North and east of Gibbons Pass the Continental Divide continues roughly in a northeast direction along the Anaconda Range crest for approximately 20 miles (32 kilometers) as the crow flies, but longer as the Continental Divide twists and turns, and is the divide between north-oriented drainage to the Pacific Ocean and south-oriented drainage to the Atlantic Ocean. Numerous saddles, some of which are more than 300 feet (91 meters) deep, notch this Continental Divide segment and link north-oriented tributaries to the west-, southwest-, and northwest-oriented East Fork Bitterroot River (EBI in Figure 5) with the southwest-oriented Trail Creek headwaters valley and further east with southeast-oriented valleys leading to the Big Hole Basin. These saddles suggest multiple south-oriented channels moved water across this Continental Divide segment into what is now the Big 
Hole River drainage basin and also in a southwest direction toward the Gibbons Pass location. Later as the Bitterroot River drainage basin flow reversal was taking place much of the southwest-oriented flow was captured by headward erosion of the north-oriented East Fork Camp Creek valley. Headward erosion of the west- and southwest-oriented East Fork Bitterroot River (EBI) headwaters valley next captured south-oriented flow channels in sequence from the west to the east and created what is today the Bitterroot-Big Hole River divide (also the Continental Divide). Many high Anaconda Range areas along the Continental Divide were later glaciated with glaciation occurring after the drainage divide had been created.

2) Cutaway and Storm Lake Passes (numbers 18 and 19 on Figure 2) have elevations of 9036 feet (2754 meters) and 9131 feet (2783 meters) respectively. Both are high altitude saddles notched into the glaciated Anaconda Range crest ridge. Cutaway Pass is a 800 -foot (244 meters) deep saddle located on the arête between a northeast-oriented cirque draining to northwest- and north-oriented East Fork Rock Creek (with water eventually reaching northwest-oriented Clark Fork-F on Figure 1) and a southwest-oriented cirque draining to southeast-oriented LaMarche Creek with water flowing to the east- and south-oriented Big Hole River. The Cutaway Pass orientation suggests erosion may have been initiated by southwest-oriented flow, but the longer opposing valley orientations suggests most water that once flowed through the Pass probably moved from the northwest to the southeast. Storm Lake Pass is located on another arête separating the north-oriented Storm Lake Creek valley from the southeast-oriented Seymour Creek valley. North-oriented Storm Lake Creek flows to southeast- and northeast-oriented Warm Springs Creek (WS in Figure 6), which joins Silver Bow Creek (SB in Figure 6) to form north- and northwest-oriented Clark Fork

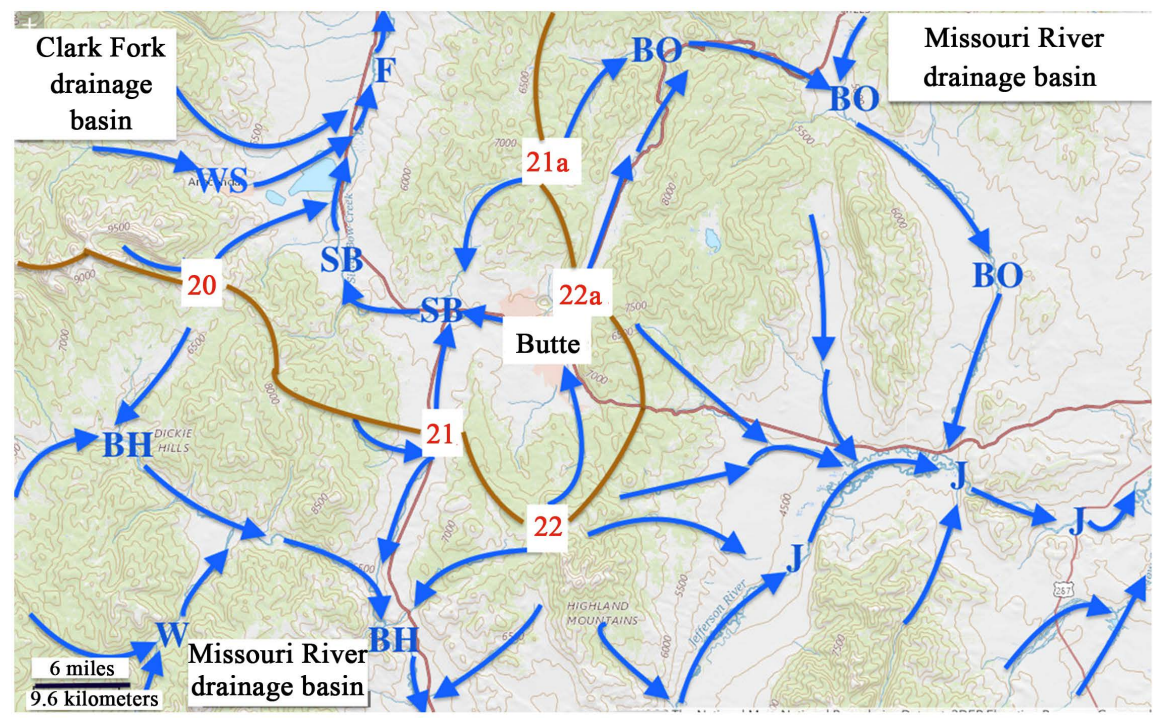

Figure 6. Modified section of USGS National Map website map showing locations of passes 20 - 22. Red numbers show pass locations and blue letters identify drainage routes as indicated in the text. A brown line follows the east-west Continental Divide. 
(F on Figure 1). Seymour Creek flows to the east- and south-oriented Big Hole River (BH). Cutaway and Storm Lake Passes are typical of saddles notched into the glaciated Anaconda Range crest.

3) Anaconda-Ralston Road Pass (number 20 on Figure 2 and Figure 6) has an elevation of 6772 feet (2064 meters). About one mile (1.6 kilometers) northwest of the Anaconda-Ralston Road Pass the Continental Divide rises to an elevation of 7990 feet (2435 meters) at Grassy Mountain while about the same distance to the southeast the Continental Divide rises to 7766 (2337 meters) feet at Sugarloaf Mountain. A north-oriented valley drains from the Anaconda-Ralston Road Pass to east- and northeast-oriented Mill Creek with water eventually reaching north-oriented Silver Bow Creek (SB on Figure 6) and north- and northwest-oriented Clark Fork (F on Figure 1 and Figure 6). A south-oriented valley leads from the Anaconda-Ralston Road Pass to southwest- and south-oriented California Creek, which joins the Big Hole River (BH) at an elevation of about 5760 feet (1756 meters) just before it turns to flow in a southeast and south direction. The Anaconda-Ralston Road Pass was eroded by south-oriented water prior to headward erosion of the east-oriented Mill Creek and Warm Springs (WS) Creek valleys to the north. Headward erosion of those deep east-oriented valleys diverted south-oriented flow to the north-south oriented structural valley crossed by Deer Lodge Pass (number 21).

4) Deer Lodge Pass (number 21 on Figure 2 and Figure 6) with an elevation of 5801 feet or 1768 meters is located in a broad 3-mile (4.8 kilometers) wide north-south oriented structural valley. South-oriented Divide Creek flows from Deer Lodge Pass to join the south-oriented Big Hole River (BH), which as seen in Figure 2 makes a U-turn to join the north-oriented Beaverhead (B) and Ruby Rivers (RU) as a barbed tributary to form the northeast-oriented Jefferson River (J). North-oriented Sand Creek flows from Deer Lodge Pass to join west- and north-oriented Silver Bow Creek (SB), which joins Warm Springs Creek (WS) to form north- and northwest-oriented Clark Fork (F). South-oriented Brown's Gulch joins west-oriented Silver Bow Creek (SB) immediately to the north of the north-oriented Sand Creek valley. Passes or saddles, one (number 21a) with an elevation of less than 7200 feet (2195 meters), notched into the Continental Divide link the south-oriented Brown's Gulch valley with the north-oriented Boulder River (BO) valley. After flowing in a north direction the Boulder River (BO) turns to flow in an east and then south direction and eventually joins the east-oriented Jefferson River (J), which then joins the north-oriented Madison (MA) and Gallatin Rivers (GA) to form the north-, east-, and south-oriented Missouri River (M) seen in Figure 1. While a structural valley Deer Lodge Pass was probably eroded by south-oriented water that flowed from or across what is today the Boulder River (BO) drainage basin, although some south-oriented water also probably moved along the present day north-oriented Clark Fork (F) and Silver Bow Creek (SB) alignment to flow across Deer Lodge Pass.

5) Basin Creek Pass (number 22 on Figure 2 and Figure 6) with an elevation of 7309 feet (2228 meters) is the easternmost of several passes linking 
north-oriented drainage to Clark Fork (F) with southwest-oriented drainage to the south-oriented Big Hole River segment (BH). Basin Creek Pass is not named on the topographic maps, but is named here for north-oriented Basin Creek, which originates near the Pass and then flows in a north direction between mountains rising to 8151 feet (2484 meters) on the east and to 7752 feet (2363 meters) on the west. The Middle Fork of Moose Creek originates just south of Basin Creek Pass with water flowing in a southwest direction to reach the south-oriented Big Hole River (BH). Basin Creek joins other streams at Butte to form west- and north-oriented Silver Bow Creek (SB). Basin Creek Pass, the southwest-oriented Moose Creek valley, and the present day north-oriented Basin Creek valley were probably eroded by south-oriented water that moved through Elk Park Pass (number 22a located north of the City of Butte). If so Basin Creek Pass was not eroded by water flowing from or across the present day Clark Fork (F) drainage basin, but was instead eroded by south oriented water moving from or across the drainage basin of the present day north-, east-, and south-oriented Boulder River (BO), which today joins the east-oriented Jefferson River (J), which in turn joins two north-oriented rivers to form the northwest-oriented Missouri River (M).

\section{Discussion}

Unusually large volumes of south-oriented water over prolonged periods of time eroded the southwest Montana region. Two sources for those large water volumes have been suggested, although still other possibilities may exist. First, while the present day topography was evolving the entire region could have experienced prolonged periods of much greater rainfall than at present. Alt and Hyndman [19] describe western Montana during Miocene time as being much warmer and wetter than now. They suggest Miocene rainfall produced streams and even large rivers that flowed through "tropical and subtropical" forests. Complexes of south-oriented anastomosing channels could have developed under such conditions especially if tectonic activity blocked drainage routes and forced water to spill from subsiding basin areas across the emerging mountain ranges into adjacent subsiding basin areas. Such an interpretation, while maybe consistent with current interpretations of sediment and fossil evidence, does not provide a good explanation as to why vast quantities of water overflowed the emerging mountain ranges in closely spaced streams and rivers or why until quite late during the regional drainage history the water appears to have almost always overflowed in a south direction. Nor does such an explanation provide a good explanation for the many barbed tributaries and drainage route U-turns found throughout the southwest Montana region.

An alternate large water source might be a large North American ice sheet. A thick North American ice sheet at its maximum extent probably would have contained enough water to fill a medium sized ocean. Melting of such an ice sheet would generate vast volumes of south-oriented water. Excellent evidence 
suggests one or more large ice sheet margins were located in what are today northern Missouri River (M) and Clark Fork (F) drainage basin areas. Today the Montana Missouri River (M) flows in a north direction toward the ice sheet margin areas and then in an east and southeast direction along or near the former ice sheet margins. Clausen [20] [21] described evidence for headward erosion of deep north- and northeast-oriented valleys (perhaps eroding headward from space in an ice sheet created and occupied deep "hole" that was being opened up as the ice sheet melted) across massive southeast-oriented ice marginal melt water floods that flowed across western South Dakota and southeast Montana, but raised questions about when those floods occurred. Previous researchers associated some evidence Clausen [21] used with Oligocene and/or Miocene sediments (and fossils) and large North American ice sheets are not presently known to have existed during Oligocene and/or Miocene time.

North- and northwest-oriented Clark Fork (F) also flows toward a documented ice sheet margin and is joined by the south-oriented Flathead River, which at one time must have flowed from that ice sheet margin. Ice sheet melt water probably from the Flathead River drainage basin filled Lake Missoula, which is interpreted in Baker [22] to have catastrophically drained during late Pleistocene time so as to deeply erode the Washington State Channeled Scablands. The north- and northwest-oriented Clark Fork (F) drainage basin is usually assumed to have already been in existence when giant floods eroded the Washington State Channeled Scablands. However it is possible much of the Washington State flooding occurred earlier than commonly thought and large volumes of ice sheet melt water also moved in a south direction to erode this paper's southwest Montana study region. An ice sheet melt water source is more consistent with the mountain pass and other drainage history evidence than the previously described Miocene rainfall hypothesis, but such an ice sheet to explain all of the evidence described here must have created and occupied a deep "hole" in the North American continent. The opening up of space in that deep "hole" as the large ice sheet melted is necessary to explain headward erosion of deep north- and northeast-oriented valleys across massive south -and southeast-oriented ice marginal melt water floods so as to create the previously mentioned Bell River system of north-oriented valleys and to behead and reverse flow in what is today Montana's north-oriented Missouri River (M) valley segment.

\section{Conclusions}

Detailed topographic map evidence documents large volumes of south-oriented water eroded what are today the numerous deep passes and shallower saddles that are notched into North America's east-west Continental Divide and the Big Hole-Beaverhead River divide. All observed passes and saddles, with the possible exceptions of Deer Lodge and Hidden Lake Passes, through which south-oriented water almost certainly flowed, appear to be erosional features carved by numerous and closely spaced south-oriented rivers or streams that once flowed 
across what are now North America's east-west Continental Divide and the Big Hole-Beaverhead River drainage divide. Valley orientations, numerous south-oriented barbed tributaries flowing to modern-day north-oriented rivers, present-day drainage route U-turns, and similar features are all consistent with an earlier south-oriented drainage system that was subsequently captured and reversed to create the central and southwest Montana north-oriented Missouri River (M) drainage system.

Present-day pass and saddle floor elevations suggest tectonic activity raised mountain ranges relative to adjacent valleys and subsiding basins as the south-oriented rivers and streams flowed across the region. The numerous passes and saddles notched into what are today the Anaconda and Beaverhead Mountain Range crests suggest great numbers of closely spaced south-oriented channels moved large volumes of water across a region of low relief as emergence of those mountain ranges began. Initially water probably flowed in large anastomosing complexes of diverging and converging channels, although deeper passes suggest repeated capture events gradually consolidated the south-oriented flow into fewer and fewer and much deeper south-oriented valleys until finally crustal warping and additional capture events systematically caused flow reversals that eventually resulted in the present-day southwest Montana drainage system.

The earliest evidence for south-oriented water erosion is found in Anaconda, Beaverhead, and Pioneer Mountain passes and saddles. South-oriented drainage across what must have been a subsiding Big Hole Basin was diverted by Beaverhead Mountain uplift so as to flow in a southeast direction along the southeast-oriented Bloody Dick Creek (BD) alignment to Bannock, Deadman, Bannack, and Monida Passes and also to passes at the east end of what must have been a subsiding Centennial Valley. Crustal warping eventually ended southeast-oriented flow from the Big Hole Basin to Bannock, Deadman, and Bannack Passes although south-oriented flow on the Beaverhead River (B) alignment continued to reach Monida Pass and passes at the Centennial Valley eastern end.

At the same time as the above described events were taking place headward erosion of the deep south-oriented North Fork Salmon River valley was capturing south-oriented flow that was moving into the Big Hole Basin. Headward erosion of the deep east-oriented Big Hole River $(\mathrm{BH})$ valley segment (between the Anaconda Range and Pioneer Mountains) next beheaded and reversed southwest- and south-oriented flow moving to the North Fork Salmon River (NSA in Figure 5) valley so as to create the north-, east-, and south-oriented Big Hole River $(\mathrm{BH})$ drainage system. Crustal warping by this time had reversed south-oriented flow across the present day north-oriented Bitterroot River (BI) drainage basin due to Anaconda Range emergence. Continued crustal warping and a major flow reversal in what is today Montana's north-oriented Missouri River (M) valley finally reversed Jefferson River (J) flow, which reversed flow in the Beaverhead (B) and Red Rock River (R) valleys so as to create the north-oriented drainage systems seen today. Glaciation in newly uplifted Ana- 
conda, Beaverhead, and Pioneer Mountain regions further modified some of the valleys and drainage divides.

\section{References}

[1] United States Geological Survey National Map Website. https://viewer.nationalmap.gov/advanced-viewer/

[2] Umpleby, J.B. (1913) Geology and Ore Deposits of Lemhi County. United States Geological Survey Bulletin 528, Idaho.

[3] Atwood, W.W. (1916) The Physiographic Conditions at Butte, Montana, and Bing-Ham Canyon, Utah, When the Copper in These Districts Was Enriched. Economic Geology, 11, 697-740. https://doi.org/10.2113/gsecongeo.11.8.697

[4] Kirkham, V.R.D. (1927) A Geologic Reconnaissance of Clark and Jefferson and Parts of Butte, Custer, Fremont, Lemhi, and Madison Counties, Idaho. Idaho Bureau Mines and Geology Pamphlet 19.

[5] Perry, E.S. (1934) Physiography and Groundwater Supply in the Big Hole Basin. Montana Bureau of Mines and Geology Memoir 12, Montana.

[6] Anderson, A.L. (1947) Drainage Diversion in the Northern Rocky Mountains of East-Central Idaho. Journal of Geology, 55, 61-75. https://doi.org/10.1086/625402

[7] SohoItch, R., Keenmort, K.A. and Kupsch, W.O. (1955) Geology of the Lima Region, Southwestern Montana, and Adjacent Idaho. Geological Society America Bulletin, 66, 345-404. https://doi.org/10.1130/0016-7606(1955)66[345:GOTLRS]2.0.CO;2

[8] Ruppel, E.T. (1967) Late Cenozoic Drainage Reversal, East-Central Idaho, and Its Relation to Possible Placer Deposits. Economic Geology, 62, 648-663. https://doi.org/10.1130/0016-7606(1955)66[345:GOTLRS]2.0.CO;2

[9] Bayrd, G.B. (2006) Influences of Geology and Water Management on Hydrology and Fluvial Geomorphology in the Henry's Fork of the Snake River, Eastern Idaho and Western Wyoming. Master's Thesis, Idaho State University, Pocatello, 27-29.

[10] Sears, J.W. (2013) Late Oligocene-Early Miocene Grand Canyon: A Canadian Connection? GSA Today, 23, 4-10. https://doi.org/10.1130/GSATG178A.1

[11] Sears, J.W. (2014b) Tracking a Big Miocene River across the Continental Divide at Monida Pass, Montana/Idaho. In: Shaw, C.A. and Tikoff, B., Eds., Exploring the Northern Rocky Mountains: Geological Society of America Field Guide, 37, 89-100.

[12] McMillan, J.N. (1973) Shelves of the Labrador Sea and Baffin Bay, Canada. Canadian Society of Petroleum Geologists Memoir 1, 473-515.

[13] Clausen, E. (2014) Comment: "Late Oligocene-early Miocene Grand Canyon: A Canadian connection?” Online: GSA Today, Comments and Replies. https://www.geosociety.org/gsatoday/comment-reply/pdf/i1052-5173-24-4-e32.pdf

[14] Sears, J.W. (2014a) Reply to Comment: "Late Oligocene-Early Miocene Grand Canyon: A Canadian Connection?" Online: GSA Today, Comments and Replies. https://www.geosociety.org/gsatoday/comment-reply/pdf/i1052-5173-24-4-e33.pdf

[15] United States Geological Survey Historical Map Collection Website. https://ngmdb.usgs.gov/topoview/viewer/\#4/39.98/-99.93

[16] Gary, S.D. (1980) Quaternary Geology and Geophysics of the Upper Madison Valley, Madison County, Montana. Master's Thesis, University of Montana, Missoula, Montana.

[17] Hill, C.L. (2005) Geology of Centennial Valley and Stratigraphy of Pleistocene Fos- 
sil-Bearing Sediments. Master's Thesis, Boise State University, Boise, Idaho.

[18] Beranek, L.P., Link, P.K. and Fanning, C.M. (2006) Miocene to Holocene Land-Scape Evolution of the Western Snake River Plain Region, Idaho: Using the SHRIMP De-Trital Zircon Record to Track Eastward Migration of the Yellowstone Hotspot: Geological Society of America Bulletin, 118, 1027-1050. https://doi.org/10.1130/B25896.1

[19] Alt, D.D. and Hyndman, D.W. (1986) Roadside Geology of Montana. Mountain Press Publishing Company, Missoula, Montana, 428 p.

[20] Clausen, E. (2017) Solving a Perplexing Scenic and Sage Creek Basin Drainage History Problem, Pennington County, South Dakota, USA. Journal of Geography and Geology, 9, 1-10. https://doi.org/10.5539/jgg.v9n2p1

[21] Clausen, E. (2017) Origin of Little Missouri River-South Fork Grand River and nearby Drainage Divides in Harding County, South Dakota and Adjacent Eastern Montana, USA. Open Journal of Geology, 7, 1063-1077. https://doi.org/10.4236/ojg.2017.78071

[22] Baker, V.R., Ed. (1981) Catastrophic Flooding: The Origin of the Channeled Scabland. Dowden, Hutchinson and Ross, Inc., Stroudsburg, PA.

\section{Submit or recommend next manuscript to SCIRP and we will provide best service for you:}

Accepting pre-submission inquiries through Email, Facebook, LinkedIn, Twitter, etc. A wide selection of journals (inclusive of 9 subjects, more than 200 journals)

Providing 24-hour high-quality service

User-friendly online submission system

Fair and swift peer-review system

Efficient typesetting and proofreading procedure

Display of the result of downloads and visits, as well as the number of cited articles

Maximum dissemination of your research work

Submit your manuscript at: http://papersubmission.scirp.org/

Or contact ojg@scirp.org 